\title{
Cholinergic Urticaria, an Effective and Safe "Off Label” Use of Dupilumab: A Case Report with Literature Review
}

\author{
Maria Maddalena Sirufo $\mathbb{D}^{1,2}$, Alessandra Catalogna $\mathbb{D}^{1,2}$, Martina Raggiunti $\mathbb{D}^{1,2}$, \\ Francesca De Pietro $\mathbb{D}^{1,2}$, Lia Ginaldi $\mathbb{D}^{1,2}$, Massimo De Martinis $\mathbb{( D}^{1,2}$ \\ 'Department of Life, Health and Environmental Sciences, University of L’Aquila, L'Aquila, Italy; ${ }^{2}$ Allergology and Clinical Immunology Unit, “Mazzini” \\ Hospital AUSL 04 Teramo, Teramo, Italy
}

Correspondence: Massimo De Martinis, Department of Life, Health and Environmental Sciences, University of L'Aquila, Piazzale Salvatore Tommasi n. I, L’Aquila, 67 I00, Italy, Tel +39 086I 429548, Fax +39 086I 21 I395, Email demartinis@cc.univaq.it

\begin{abstract}
Cholinergic Urticaria (CholU) is a form of generalized urticaria induced by an increase in core body temperature that activates the sweat reflex. Clinically it is characterized by localized and highly itchy wheals with surrounding erythema and can occur in response to exercise, hot baths and/or emotional stress. Dupilumab is a fully human monoclonal antibody specifically designed to simultaneously inhibit the activity of interleukin-4 (IL-4) and interleukin-13 (IL-13), which play a key role in the inflammation cascade of type 2. We report the case of a 26-year-old man suffering from CholU for 3 years, unresponsive to standard treatment in which off-label therapy was undertaken with Dupilumab, $600 \mathrm{mg}$ subcutaneous as a loading dose and then $300 \mathrm{mg}$ every 15 days. The daily Visual Analogue Scale (VAS) score was used to assess the efficacy of the therapy. Already after the first two administrations, the patient no longer had CholU episodes and resumed regular sporting activity, with a marked improvement in the quality of life. A possible mechanism of Dupilumab in reducing the manifestations of CholU is the blocking of the IL-4 pathway and the expression of the high-affinity IgE receptor (FceR1) on B cells, mast cells (MCs) and basophils. By decreasing the production of FceR1, the adhesion of $\mathrm{IgE}$ to the surface of MCs decreases with consequent reduction of MCs activation and histamine release. Further experience and large-scale studies may be needed to establish whether Dupilumab can be a therapeutic alternative in CholU, especially in patients who do not respond to standard treatment.
\end{abstract}

Keywords: Dupilumab, Cholinergic Urticaria, atopic dermatitis, interleukin-4, interleukin-13, acetylcholine, CholU, AD

\section{Introduction}

Cholinergic Urticaria (CholU) is as a subtype of chronic inducible urticaria caused by an increase in the core body temperature, such as to activate the sweating reflex. ${ }^{1}$ It can occur in response to physical exercise, hot bathing and/or emotional stress. Clinically it appears as pinpointing and highly pruritic wheals with surrounding erythema. ${ }^{2,3}$ The CholU can be accompanied by severe symptoms such as angioedema, respiratory symptoms or anaphylaxis. The diagnosis of CholU, according to the European Guidelines for $\mathrm{CholU}^{4}$ is based on provocation tests with physical exercise (e.g., on a treadmill or stationary bike) to be carried out up to the point of sweating which usually occurs after 10-15 minutes of exercise and then continued running for an additional 15 minutes. The test result is generally considered positive if the typical rash appears within 10 minutes from starting sweating. If positive, at least 24 hours later, a passive warm-up test with a full bath at $42^{\circ} \mathrm{C}$ should be performed for up to 15 minutes to rule out induced anaphylactic exercise. The current EAACI/GA2LEN/EDF/UNEV consensus recommended, as the best approach for CholU, H1 antihistamines and updosing in non-responders, along with avoidance of the trigger. In refractory cases, Omalizumab, a recombinant humanized IgG1 monoclonal antibody that binds to IgE can be considered. ${ }^{5-10}$ Therapeutic variations including addition of an $\mathrm{H} 2$ receptor antagonist, Montelukast, Scopolamine, ${ }^{11}$ Danazol, ${ }^{12,13} \beta 2$ - adrenergic stimulants, ${ }^{14} \beta 2$-adrenergic blockers ${ }^{15}$ and Botulinum toxin injection has been reported as an effective treatment. Desensitization therapy involving regular physical 
exercise or treatment with autologous sweat may become a choice of treatment for patients with sweat hypersensitivity. ${ }^{16,17}$ Dupilumab is a fully human monoclonal antibody specifically designed to simultaneously inhibit the activity of two cytokines, interleukin-4 (IL-4) and interleukin 13 (IL-13), that have a key role in the cascade of inflammation type 2, at the base of numerous pathologies, such as atopic dermatitis (AD), severe asthma, nasal polyposis, eosinophilic esophagitis, prurigo nodularis and Chronic Spontaneous Urticaria (CSU). Dupilumab is currently indicated for the treatment of severe $\mathrm{AD}$ in children from 6 years of age, for mild-severe $\mathrm{AD}$ in adolescents from 12 years old and adults who are candidates for systemic therapy. ${ }^{18}$ Age-related indications for Dupilumab for AD vary from country to country. Another indication is in adults and adolescents over 12 years old as add-on maintenance treatment for severe asthma with type 2 inflammation, characterized by raised blood eosinophils and/or raised fraction of exhaled nitric oxide (FeNO), who are inadequately controlled with high dose ICS plus another medicinal product for maintenance treatment. Dupilumab is also indicated as an add-on therapy with intranasal corticosteroids for the treatment of adults with severe CRSwNP for whom therapy with systemic corticosteroids and/or surgery do not provide adequate disease control. Föhr et al described a case of a young 21-year-old woman with CSU with angioedema, CholU and AD treated with Omalizumab with poor results. Therefore, therapy with Dupilumab was opted achieving complete healing of AD, complete remission of CSU with angioedema and satisfactory control of cholinergic exacerbations for a follow-up period of 26 weeks. ${ }^{19}$ Based on case series reports found in literature, Dupilumab appears to be useful, effective and safe also in the treatment of CSU in patients unresponsive to treatment with $\mathrm{H} 1$ antihistamines, oral corticosteroids, antileukotrienes, Omalizumab and cyclosporine., ${ }^{50-22}$

\section{Case Report}

We report on a case of a 26-year-old man affected by CholU for 3 years. He had no significant medical history, in particular no history of allergic rhinoconjunctivitis, asthma, AD in childhood or other allergic diseases and the patient was not taking drugs. The patient does not refer hyperhidrosis and according to the Hyperhidrosis Disease Severity Scale (HDSS) the score at the basal valutation was valutated $1 .{ }^{23}$ Skin lesions present highly pruritic and pinpointing wheals with surrounding erythema especially in the photo-exposed regions, after physical exercise, even with low intensity

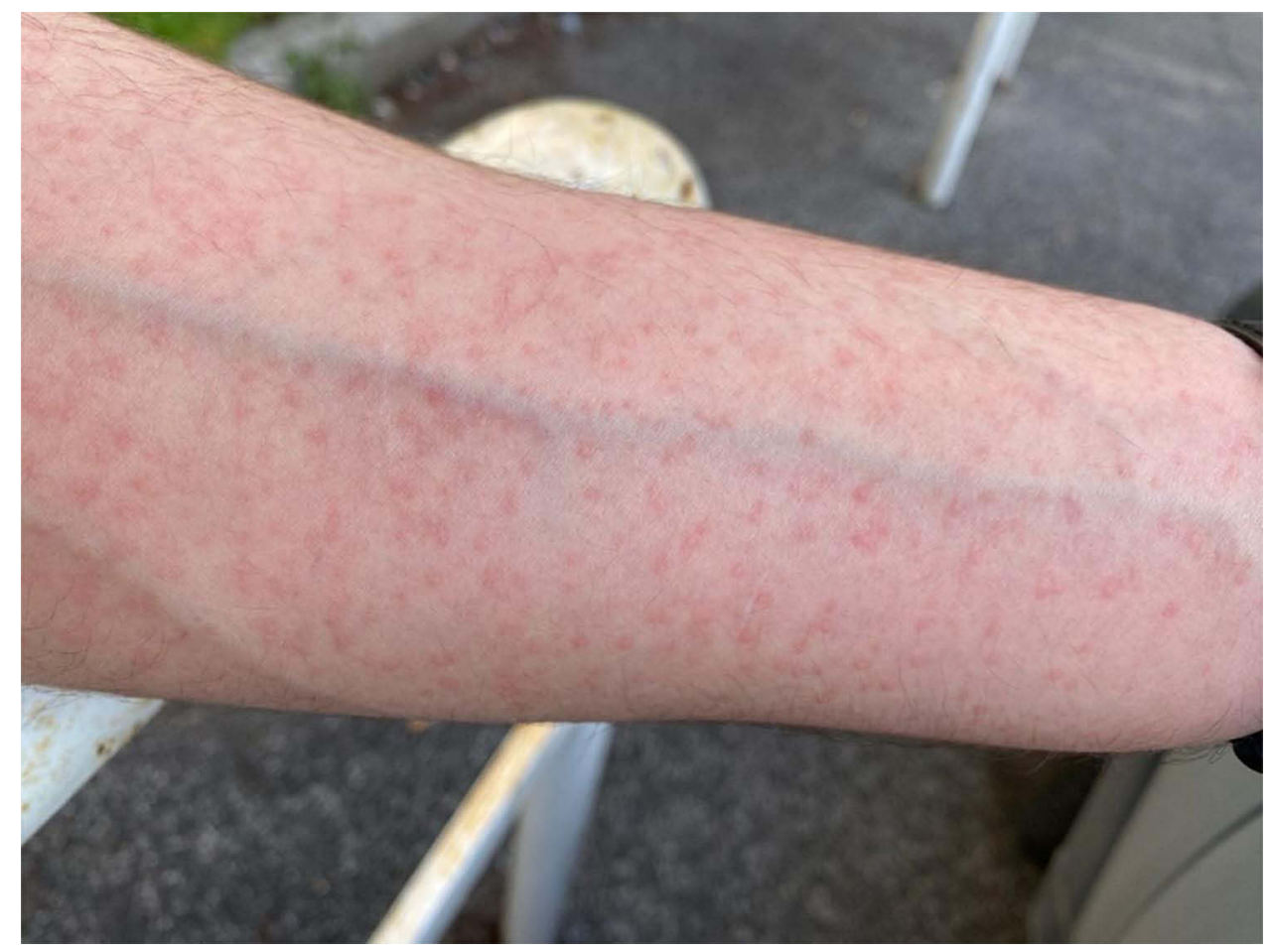

Figure I Pinpointing wheals in left arm. 
Table I Laboratory Tests

\begin{tabular}{|c|c|c|}
\hline Laboratory Tests & Value & Reference Ranges \\
\hline \multicolumn{3}{|l|}{ BLOOD CELLS COUNT } \\
\hline Leukocyte & $6.20 \times 10^{3} / \mu \mathrm{L}$ & $4.00-10.00$ \\
\hline Neutrophils & $3.33 \times 10^{3} / \mu \mathrm{L}$ & $2.00-7.00$ \\
\hline Lymphocytes & $2.24 \times 10^{3} / \mu \mathrm{L}$ & $1.00-4.00$ \\
\hline Monocytes & $0.37 \times 10^{3} / \mu \mathrm{L}$ & $0.20-1.00$ \\
\hline Eosinophils & $0.09 \times 10^{3} / \mu \mathrm{L}$ & $0.02-0.50$ \\
\hline Basophils & $0.05 \times 10^{3} / \mu \mathrm{L}$ & $0.00-0.20$ \\
\hline Erythrocyte & $4.83 \times 10^{6} / \mu \mathrm{L}$ & $3.8-4.8$ \\
\hline Platelet & $262 \times 10^{3} / \mu \mathrm{L}$ & $150-450$ \\
\hline Erythrocyte sedimentation rate (ESR) & $8 \mathrm{~mm}$ & $1.0-15.0$ \\
\hline C-reactive protein (CRP) & $2.3 \mathrm{mg} / \mathrm{dL}$ & $0.00-5.00$ \\
\hline \multicolumn{3}{|l|}{ KIDNEY FUNCTION } \\
\hline Creatinine & $0.08 \mathrm{mg} / \mathrm{dL}$ & $0.5-0.9$ \\
\hline Azotemia & $34 \mathrm{mg} / \mathrm{dL}$ & $10.0-50.0$ \\
\hline \multicolumn{3}{|l|}{ LIVER FUNCTION } \\
\hline Aspartate aminotransferase (AST) & $25 \mathrm{U} / \mathrm{L}$ & $4-32$ \\
\hline Alanine aminotransferase (ALT) & $28 \mathrm{U} / \mathrm{L}$ & $4-32$ \\
\hline \multicolumn{3}{|l|}{ COAGULATION TEST } \\
\hline \multirow[t]{2}{*}{ Prothrombin time (PT) } & $96 \%$ & $70.0-130$ \\
\hline & $11.7 \mathrm{sec}$ & $10.0-14$ \\
\hline International normalized ratio (INR) & 10.3 & $0.80-1.30$ \\
\hline Partial thromboplastin time (PTT) & $25 \mathrm{sec}$ & 23 \\
\hline \multicolumn{3}{|l|}{ AUTOIMMUNE TESTS } \\
\hline Antinuclear antibodies (ANA) & Negative & Negative \\
\hline Extractable nuclear antigen (ENA) SCREENING (anti-Sm, RNP, Ro60, Ro62, SS-B, SCl-70, Jo-I) & $<3.6 \mathrm{U} / \mathrm{mL}$ & $<20$ \\
\hline Anti-neutrophil cytoplasm antibodies (ANCA) directed against myeloperoxidase (MPO) & $<3.20 \mathrm{U} / \mathrm{mL}$ & $<20$ \\
\hline ANCA- directed against proteinase-3 (PR3) & $<2.30 \mathrm{U} / \mathrm{mL}$ & $<20$ \\
\hline Antiplatelet antibodies & Absent & Absent \\
\hline Anti cardiolipin IgG antibodies & $0.40 \mathrm{U} / \mathrm{mL}$ & $<7$ \\
\hline Anti cardiolipin IgM antibodies & $0.20 \mathrm{U} / \mathrm{mL}$ & $<7$ \\
\hline Anti $\beta 2$-glycoprotein $\lg G$ antibodies & $0.73 \mathrm{U} / \mathrm{mL}$ & $<7$ \\
\hline Anti $\beta 2$-glycoprotein IgM antibodies & $5 \mathrm{U} / \mathrm{mL}$ & $<7$ \\
\hline Anti-double stranded DNA (Anti-dsDNA) antibodies & Negative & Negative \\
\hline
\end{tabular}

(Continued) 
Table I (Continued).

\begin{tabular}{|c|c|c|}
\hline Laboratory Tests & Value & Reference Ranges \\
\hline \multicolumn{3}{|l|}{ TUMOR MARKERS } \\
\hline Carcino-Embryonic Antigen (CEA) & $1.48 \mathrm{ng} / \mathrm{mL}$ & $0.00-4.70$ \\
\hline Carbohydrate Antigen (CA) 19.9 & $19.4 \mathrm{U} / \mathrm{mL}$ & $0.00-39$ \\
\hline Alpha Fetoprotein (AFP) & $2.23 \mathrm{IU} / \mathrm{mL}$ & $0.5-5.50$ \\
\hline \multicolumn{3}{|l|}{ IMMUNOGLOBULINS } \\
\hline Cryoglobulin & Absent & Absent \\
\hline Immunoglobulin G & $1220 \mathrm{mg} / \mathrm{dL}$ & $700.0-1600.0$ \\
\hline Immunoglobulin A & $325 \mathrm{mg} / \mathrm{dL}$ & $70.0-400.0$ \\
\hline Immunoglobulin $\mathrm{M}$ & 107 mg/dl & $40.0-230.0$ \\
\hline \multicolumn{3}{|l|}{ IN VITRO ALLERGY TESTS } \\
\hline Total lgE & $65 \mathrm{IU} / \mathrm{mL}$ & $0.00-100.00$ \\
\hline Tryptase & $4.06 \mu g / L$ & $1.00-8.00$ \\
\hline Eosinophil cationic protein (ECP) & $10 \mu g / L$ & $1.00-12.00$ \\
\hline Specific IgE to Dermatophagoides farinae & $0.01 \mathrm{kUA} / \mathrm{L}$ & $0.0-0.35$ \\
\hline Specific lgE to Dermatophagoides pteronyssinus & $0.05 \mathrm{kUA} / \mathrm{L}$ & $0.0-0.35$ \\
\hline Specific lgE to grasses & $0.20 \mathrm{kUA} / \mathrm{L}$ & $0.0-0.35$ \\
\hline Specific IgE to logliarella & $0.16 \mathrm{kUA} / \mathrm{L}$ & $0.0-0.35$ \\
\hline Specific IgE to birch & $0.12 \mathrm{kUA} / \mathrm{L}$ & $0.0-0.35$ \\
\hline Specific IgE to cat epithelium & $0.03 \mathrm{kUA} / \mathrm{L}$ & $0.0-0.35$ \\
\hline Specific lgE to dog epithelium & $0.04 \mathrm{kUA} / \mathrm{L}$ & $0.0-0.35$ \\
\hline Specific lgE to peanuts & $0.19 \mathrm{kUA} / \mathrm{L}$ & $0.0-0.35$ \\
\hline Specific lgE to tomato & $0.00 \mathrm{kUA} / \mathrm{L}$ & $0.0-0.35$ \\
\hline Specific lgE to soy & $0.01 \mathrm{kUA} / \mathrm{L}$ & $0.0-0.35$ \\
\hline Specific IgE to strawberry & $0.03 \mathrm{kUA} / \mathrm{L}$ & $0.0-0.35$ \\
\hline Specific lgE to peach & $0.09 \mathrm{kUA} / \mathrm{L}$ & $0.0-0.35$ \\
\hline \multicolumn{3}{|l|}{ PARASITOLOGICAL EXAMINATION } \\
\hline Parasitological feces & Negative & Negative \\
\hline
\end{tabular}

efforts such as climbing stairs, with a strong negative impact on the patient's quality of life considering that he practices running at non-competitive levels (Figure 1). The provocation test conducted with moderate exercise appropriate to the age and general condition of the patient was performed up to the point of sweating and lasted until the onset of symptoms with positive test (skin rash in $10 \mathrm{~min}$ ). In the absence of treadmills in our Department, the test was conducted outdoors monitoring heart rate and at the external temperature of $21^{\circ} \mathrm{C}$ and under the supervision of a clinician. Laboratory analyses revealed normal blood count and biochemical profile, normal serum levels of total IgE and eosinophilic cationic protein (ECP), normal inflammation indices such as erythrocyte sedimentation rate (ESR) and C-reactive protein (CRP). 


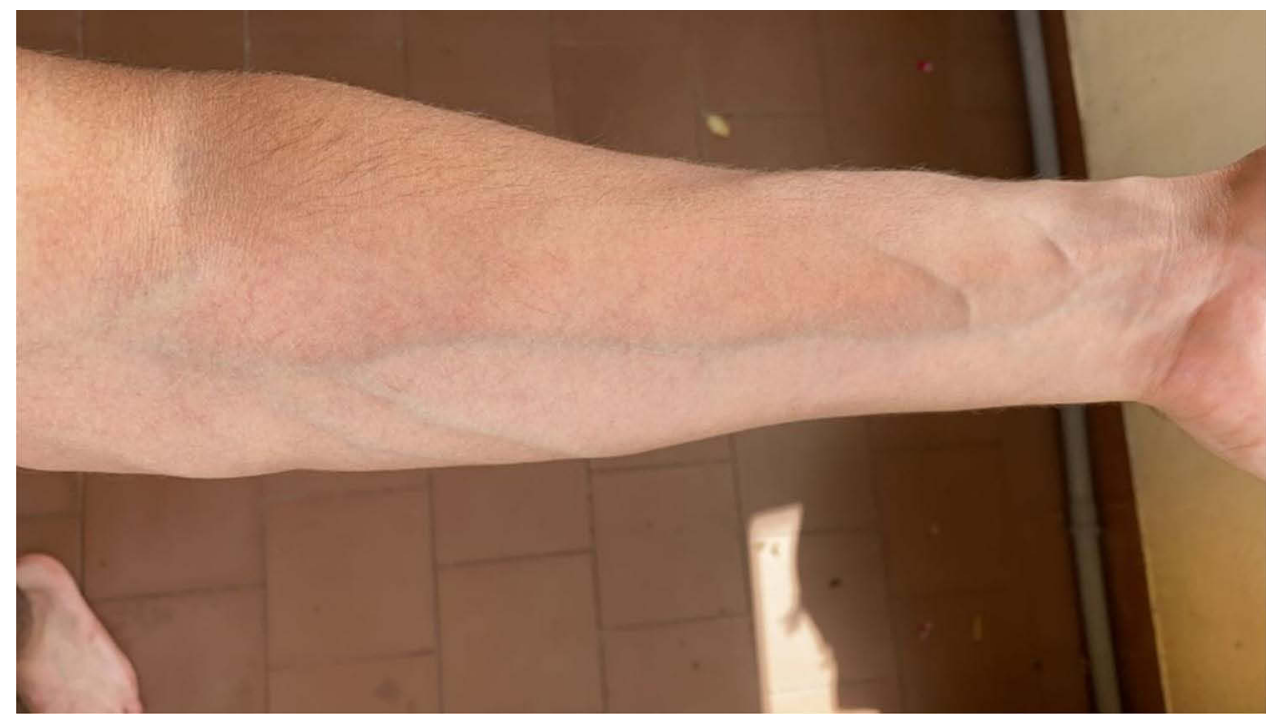

Figure 2 Absence of lesions in left arm after exercise test during therapy with Dupilumab.

Thyroid function, serum protein electrophoresis, and urinalysis were in the normal ranges. Antinuclear antibodies (ANA), anti-extractable nuclear antigens (ENA), neutrophil anti-cytoplasmic antibodies (ANCA), tumor markers, cryoglobulins and the parasitological faeces also had negative results (Table 1). Instrumental examinations, urea breath test, electrocardiogram, chest X-ray, abdominal ultrasound, did not reveal significant pathological findings. Patch test (SIDAPA) and prick tests for inhalants and food gave both negative results. In this case the disease did not respond to standard treatment (Rupatadine $10 \mathrm{mg}$ and Hydroxyzine $25 \mathrm{mg}$ even at four times the standard dose, Prednisone $25 \mathrm{mg}$, Montelukast $10 \mathrm{mg}$, Omalizumab $300 \mathrm{mg}$ every month for six months) for CholU. On the basis of the comforting data in literature about CSU, with the patient's informed consent and in compliance with the rules of our Institute, off-label therapy with Dupilumab was undertaken, $600 \mathrm{mg}$ as a loading dose and then $300 \mathrm{mg}$ every 15 days for six months. Monthly Visual Analogue Scale (VAS) score has been used to evaluate the effectiveness of the therapy with Dupilumab which values the overall disease bother. VAS score is a $10 \mathrm{~cm}$ scale with 0 meaning no disease bother and 10 being severely bothered by disease. The patients mark the scale at the point they feel corresponds to their disease bother, indicating the overall severity of their urticaria. After the first two administrations the patient already had no more episodes of CholU (Figure 2). He has resumed regular sporting activity, with a marked improvement in the quality of life. The VAS score equal to 10 before therapy (T0) reached zero from the second month, remaining negative at 6 months of observation during therapy (Table 2). During Dupilumab therapy the patient needed Rupatadine $10 \mathrm{mg}$ four times a day for the first fifteen days, then reduced doses until the antihistamine was eliminated after two months. The patient is continuing the treatment with regular follow-up and without any Dupilumab-induced adverse effect.

This work was conducted after receiving the patient's informed consent to participate in the study and to publish this report and images, in compliance with the ethical standards in the field and the norms established by the Internal Review Board of University of L'Aquila (comitato etico di Ateneo D.R. n. 206/2013 and D.R. n. 46/2017).

Table 2 VAS Improvement During Therapy with Dupilumab

\begin{tabular}{|l|l|l|l|l|l|l|l|}
\hline Time(T) & T0 & First Month & Second Month & Third Month & Fourth Month & Fifth Month & Sixth Month \\
\hline VAS & 10 & 6 & 0 & 0 & 0 & 0 & 0 \\
\hline
\end{tabular}




\section{Discussion}

The patients with CholU could be categorized into three subtypes including CholU with sweat hypersensitivity, CholU with acquired anhidrosis and/or hypohidrosis and idiopathic CholU. Tanaka et al found that the sweat-induced release of histamine from basophils is mediated by specific IgE present in the sweat of patients with $\mathrm{AD} .^{24} \mathrm{In}$ normal hidrotic areas, acetylcholine released from nerves upon exercise is completely trapped by acetylcholine receptor of eccrine glands and normally induces sweating while in the hypohidrotic area, acetylcholine released upon exercise cannot be completely trapped and overflows to the adjacent MCs with consequent degranulation of the MCs and wheal development. ${ }^{25-30}$ Dupilumab inhibits the activity of IL-4 and IL-13, T2 cytokines, important regulators of itch that act as direct pruritogens or alter the sensitivity to other itch mediators. Type 2 inflammation-dominated skin diseases, including urticaria, are characterized by intense itching. In particular, in urticaria, IL-4 and IL-5 stimulate the production of IgE antibodies and subsequent binding to the Fce receptor leading to activation and degranulation of MCs. Prolonged contact with IL-4 not only increases MCs expansion, but also phenotypically and functionally reshapes the cells. FceRI cell surface expression, FceRI $\alpha$-specific mRNA and FceRImediated histamine release are all augmented by IL-4, while histamine release elicited by the non-immunological stimulus remains unaffected. IL-4 alters human skin MCs after long-term exposure mimicking chronic disorders by strengthening mast cell (MC) numbers and intensifying processes associated with allergic inflammation. IL-4 likewise enhanced FceRI expression and/or allergic stimulability. ${ }^{31-33} \mathrm{IL}-31$, notoriously involved in the pathogenesis of chronic urticaria (CU), in turn promotes the release of IL-4 and IL-13 in an autocrine cycle. This has led to the belief that directing treatment towards IL-31 (Nemolizumab) and thereby reduce the release of IL-4 and IL-13 from activated basophils or acting directly by blocking the latter (Dupilumab) may be effective in managing urticaria and therefore Phase II and Phase III studies are underway to test the efficacy and safety of Dupilumab in patients with $\mathrm{CU} .{ }^{34-36}$ A possible mechanism for Dupilumab decreasing CholU manifestations is preventing the progression of the IL-4 pathway and the expression of Fc\&R1 on B cells, MCs and basophils just as it happens in Adrenergic Urticaria. Reducing the production of Fc\&R1 decreases the adhesion of IgE on the surface of MCs with consequent reduction in MCs activation and release of histamine. ${ }^{5}$ This is the first case in the literature of use of Dupilumab in a patient suffering only from CholU with optimal response to treatment. Further experiences and large-scale studies may be necessary in order to establish whether Dupilumab can be a valid therapeutic alternative in CholU, especially in patients who do not respond to standard treatment. However, the limit of the case is the absence of standardized provocation test due to the unavailability of a treadmill because it was not possible to control the subject's running speed. In the future, a standardized protocol for testing should be established.

\section{Conclusion}

The good response to Dupilumab after the failure of all previous traditional treatments, highlights the possibility to use this biological drug in the therapy of refractory CholU. Further and large-scale studies are useful to establish if Dupilumab represents an effective alternative to traditional therapies in these patients as well as in patients with CU.

A study is in progress to assess the efficacy and safety of Dupilumab in adult patients with CholU and we await the results with great interest. ${ }^{37,38}$

\section{Acknowledgments}

The authors would like to thank Prof. Andrea Dean Bucci for English language assistance.

\section{Disclosure}

The authors report no conflicts of interest in this work.

\section{References}

1. Fukunaga A, Washio K, Hatakeyama M, et al. Cholinergic urticaria: epidemiology, physiopathology, new categorization, and management. Clin Auton Res. 2018;28(1):103-113. doi:10.1007/s10286-017-0418-6

2. Hirschmann JV, Lawlor F, English JS, Louback JB, Winkelmann RK, Greaves MW. Cholinergic urticaria. A clinical and histologic study. Arch Dermatol. 1987;123(4):462-467. doi:10.1001/archderm.1987.01660280064024 
3. Moore-Robinson M, Warin RP. Some clinical aspects of cholinergic urticaria. Br J Dermatol. 1968;80(12):794-799. doi:10.1111/j.1365-2133.1968. tb11948.x

4. Magerl M, Borzova E, Gimenez-Arnau A, et al. The definition and diagnostic testing of physical and cholinergic urticarias-EAACI/GA2LEN/EDF/ UNEV consensus panel recommendations. Allergy. 2009;64:1715-1721. doi:10.1111/j.1398-9995.2009.02177.x

5. Goodman B, Jariwala S. Dupilumab as a novel therapy to treat adrenergic urticaria. Ann Allergy Asthma Immunol. 2021;126(2):205-206. doi:10.1016/j.anai.2020.06.034

6. Magerl M, Altrichter S, Borzova E, et al. The definition, diagnostic testing, and management of chronic inducible urticarias - the EAACI/GA(2) $\mathrm{LEN} / \mathrm{EDF} / \mathrm{UNEV}$ con, the EAACI/GA(2) LEN/EDF/UNEV consensus recommendations 2016 update and revision. Allergy. 2016;71(6):780-802. doi:10.1111/all.12884

7. Bernstein JA, Lang DM, Khan DA, et al. The diagnosis and managemen, $\mathrm{t}$ of acute and chronic urticaria: 2014 update. J Allergy Clin Immunol. 2014;133(5):1270-1277. doi:10.1016/j.jaci.2014.02.036

8. Zuberbier T, Aberer W, Burtin B, Rihoux JP, Czarnetzki BM. Efficacy of cetirizine in cholinergic urticaria. Acta Derm Venereol. 1995;75:147-149. doi:10.2340/0001555575147149

9. Zuberbier T, Munzberger C, Haustein U, et al. Double-blind crossover study of high-dose cetirizine in cholinergic urticaria. Dermatology. 1996;193:324-327. doi:10.1159/000246281

10. Sirufo MM, De Pietro F, Bassino EM, Ginaldi L, De Martinis M. Translational allergy and omalizumab: the pioneer. Indian J Pharma Educ Res. 2021;55(1):s259-s264. doi:10.5530/ijper.55.1s.58

11. Tsunemi Y, Ihn H, Saeki H, Tamaki K. Cholinergic urticaria successfully treated with scopolamine butylbromide.Int. J Dermatol. $2003 ; 42: 850$.

12. Wong E, Eftekhari N, Greaves MW, Ward AM. Beneficial effects of danazol on symptoms and laboratory changes in cholinergic urticaria. $B r$ J Dermatol. 1987;116:553-556. doi:10.1111/j.1365-2133.1987.tb05877.x

13. La Shell MS, England RW. Severe refractory cholinergic urticaria treated with danazol. J Drugs Dermatol. 2006;5:664-667.

14. Kennes B, De Maubeuge J, Delespesse G. Treatment of chronic urticaria with a beta2-adrenergic stimulant. Clin Allergy. 1977;7:35-39. doi:10.1111/j.1365-2222.1977.tb01422.x

15. Conway MJ. A beta-adrenergic blocker for cholinergic urticaria. Practitioner. 1982;226:940-941.

16. Kozaru T, Fukunaga A, Taguchi K, et al. Rapid desensitization with autologous sweat in cholinergic urticaria. Allergol Int. 2011;60:277-281. doi:10.2332/allergolint.10-OA-0269

17. Nakamizo S, Egawa G, Miyachi Y, Kabashima K. Cholinergic urticaria: pathogenesis-based categorization and its treatment options. $J$ Eur Acad Dermatol Venereol. 2012;26:114-116. doi:10.1111/j.1468-3083.2011.04017.x

18. Dupixent, Summary of product characteristics, European Medicinal Agency. Available from: https://www.ema.europa.eu/en/documents/productinformation/dupixent-epar-product-information_en.pdf. Accessed February 2, 2022.

19. Föhr J, Herbst M, Jahn S. Therapie von Urtikaria und atopischer Dermatitis bei einer Patientin mit Dupilumab [Treatment of simultaneously occurring urticaria and atopic dermatitis with dupilumab]. Hautarzt. 2021;72(3):249-251. doi:10.1007/s00105-020-04675-3

20. Lee JK, Simpson RS. Dupilumab as a novel therapy for difficult to treat chronic spontaneous urticaria. J Allergy Clin Immunol Pract. 2019;7 (5):1659-1661. doi:10.1016/j.jaip.2018.11.018

21. Maurer M, Khan DA, Elieh Ali Komi D, Kaplan AP. Biologics for the use in chronic spontaneous urticaria: when and which. $J$ Allergy Clin Immunol Pract. 2021;9(3):1067-1078. doi:10.1016/j.jaip.2020.11.043

22. Errichetti E, Stinco G. Recalcitrant chronic urticaria treated with dupilumab: report of two instances refractory to H1-antihistamines, omalizumab and cyclosporine and brief literature review. Dermatol Ther. 2021;34(2). doi:10.1111/dth.14821

23. Solish N, Bertucci V, Dansereau A. A comprehensive approach to the recognition, diagnosis, and severity-based treatment of focal hyperhidrosis: recommendations of the Canadian Hyperhidrosis Advisory Committee. Dermatol Surg. 2007;(8):908-923. doi:10.1111/j.1524-4725.2007.33192.x

24. Tanaka A, Tanaka T, Suzuki H, Ishii K, Kameyoshi Y, Hide M. Semi-purification of the immunoglobulin E-sweat antigen acting on mast cells and basophils in atopic dermatitis. Exp Dermatol. 2006;15:283-290. doi:10.1111/j.0906-6705.2006.00404.x

25. Shelly WB, Shelly ED, Ho AK. Cholinergic urticaria: acetylcholine-receptor-dependent immediate-type hypersensitivity reaction to copper. Lancet. 1983;321:843-846. doi:10.1016/S0140-6736(83)91386-7

26. Baron B, Schreiber G, Sokolovsky M. Cholinergic urticaria, copper-induced hypersensitivity, and muscarinic receptor. Lancet. 1983;322:55. doi:10.1016/S0140-6736(83)90044-2

27. Tong LJ, Balakrishnan G, Kochan JP, Kinét JP, Kaplan AP. Assessment of autoimmunity in patients with chronic urticaria. J Allergy Clin Immunol. 1997;99:461-465. doi:10.1016/S0091-6749(97)70071-X

28. Sawada Y, Nakamura M, Bito T, et al. Cholinergic urticaria: studies on the muscarinic cholinergic receptor M3 in anhidrotic and hypohidrotic skin. J Invest Dermatol. 2010;130:2683-2686. doi:10.1038/jid.2010.188

29. Blandina P, Fantozzi R, Mannaioni PF, Masini E. Characteristics of histamine release evoked by acetylcholine in isolated rat mast cells. $J$ Physiol. 1980;301:281-293. doi:10.1113/jphysiol.1980.sp013205

30. Fantozzi R, Masini E, Blandina P, Mannaioni PF, Bani-Sacchi T. Release of histamine from rat mast cells by acetylcholine. Nature. 1978;273:473-474. doi:10.1038/273473a0

31. McLeod JJ, Baker B, Ryan JJ. Mast cell production and response to IL-4 and IL-13. Cytokine. 2015;75(1):57-61. doi:10.1016/j.cyto.2015.05.019

32. Xia HZ, Du Z, Craig S, et al. Effect of recombinant human IL-4 on tryptase, chymase, and Fc epsilon receptor type I expression in recombinant human stem cell factor-dependent fetal liver-derived human mast cells. J Immunol. 1997;159(6):2911-2921.

33. Babina M, Guhl S, Artuc M, et al. IL-4 and human skin mast cells revisited: reinforcement of a pro-allergic phenotype upon prolonged exposure. Arch Dermatol Res. 2016;308:665-670. doi:10.1007/s00403-016-1688-x

34. Garcovich S, Maurelli M, Gisondi P, Peris K, Yosipovitch G, Girolomoni G. Pruritus as a distinctive feature of type 2 inflammation. Vaccines (Basel). 2021;9(3):303. doi:10.3390/vaccines 9030303

35. Kolkhir P, Altrichter S, Munoz M, Hawro T, Maurer M. New treatments for chronic urticaria. Ann Allergy Asthma Immunol. 2020;124:2-12. doi:10.1016/j.anai.2019.08.014

36. Hendricks AJ, Yosipovitch G, Shi VY. Dupilumab use in dermatologic conditions beyond atopic dermatitis - a systematic review. J Dermatolog Treat. 2021;32:19-28. doi:10.1080/09546634.2019.1689227 
37. Cholinergic Urticaria - Efficacy of Dupilumab (CHED), Charite University, Berlin, Germany, ClinicalTrials.gov Identifier: NCT03749148. Available from: https://clinicaltrials.gov/ct2/show/NCT03749148. Accessed February 2, 2022.

38. Muñoz-Bellido FJ, Moreno E, Dávila I. Dupilumab: a review of present indications and uses out of indication. J Investig Allergol Clin Immunol. 2021;32. doi:10.18176/jiaci.0682

\section{Publish your work in this journal}

Clinical, Cosmetic and Investigational Dermatology is an international, peer-reviewed, open access, online journal that focuses on the latest clinical and experimental research in all aspects of skin disease and cosmetic interventions. This journal is indexed on CAS. The manuscript management system is completely online and includes a very quick and fair peer-review system, which is all easy to use. Visit http://www. dovepress.com/testimonials.php to read real quotes from published authors.

Submit your manuscript here: https://www.dovepress.com/clinical-cosmetic-and-investigational-dermatology-journal 